\title{
Skor APRI pada subyek penyakit ginjal stadium 5 hemodialisis dengan hepatitis $\mathrm{B}$ dan hepatitis $\mathrm{C}$
}

\author{
${ }^{1}$ Maria E. Jarut \\ ${ }^{2}$ Emma Sy. Moeis \\ ${ }^{2}$ Bradley J. Waleleng
}

\author{
${ }^{1}$ Kandidat Skripsi Fakultas Kedokteran Universitas Sam Ratulangi Manado \\ ${ }^{2}$ Bagian Ilmu Penyakit Dalam Fakultas Kedokteran Universitas Sam Ratulangi Manado \\ Email: Mjarut11_277@yahoo.com
}

\begin{abstract}
Chronic kidney disease (CKD) is a process with various etiology, resulting in a progressive descent in kidney function and generally end up with kidney failure that requires renal replacement therapy. One of the renal replacement therapy is hemodialysis. Subjects undergoing hemodialysis belong to the high-risk group for hepatitis B and hepatitis C. This study aimed to obtain the APRI scores in subjects CKD 5 HD with hepatitis B and hepatitis C. This was a retrospective observational descriptive study. This study was conducted from October to December 2014 in the medical record of Hemodialysis Unit Prof. Dr. R. D. Kandou Hospital Manado. The results showed that there were 64 subjects who met the inclusion criteria, consisted of 29 (45\%) subjects with CKD 5 HD and hepatitis B and 35 (55\%) subjects with CKD 5 HD and hepatitis C. Among subjects of CKD 5 HD with hepatitis B, there were $24(37.50 \%)$ males and 5 (7.81\%) females. Among subjects with CKD 5 HD and hepatitis C, there were 15 (23.43\%) males and 20 (31.25\%) females. Age range in subjects with CKD $5 \mathrm{HD}$ and hepatitis B was 37-69 years, while in subjects with CKD $5 \mathrm{HD}$ and hepatitis C was 33-65 years. The SGOT of the CKD 5 HD subjects with hepatitis B was 14-58 $\mathrm{U} / \mathrm{L}$ while of the CKD $5 \mathrm{HD}$ subjects with hepatitis C was 21-38 U/L. The platelet count in subjects with CKD $5 \mathrm{HD}$ and hepatitis B was $78.10^{3} / \mathrm{mm}^{3}-357.10^{3} / \mathrm{mm}^{3}$ while in CKD 5 HD subjects with hepatitis C was $54.10^{3} / \mathrm{mm} 3-417.10^{3} / \mathrm{mm}^{3}$. Based on the SGOT and the platelet count, the final APRI scores for subjects with CKD 5 HD and hepatitis B was 0.0040.056 while the of CKD 5 HD subjects with hepatitis $C$ was $0.005-0.177$. The APRI scores in subjects with CKD 5 HD and hepatitis B and CKD 5 HD subjects with hepatitis C was $<0.5$ which meant there was no fibrosis of the liver or fibrosis without septa. Conclusion: APRI scores were not significant to the degree of fibrosis in the early stages of either hepatitis B or hepatitis C.
\end{abstract}

Keywords: CKD 5 HD, hepatitis B, hepatitis C, APRI score

\begin{abstract}
Abstrak: Penyakit ginjal kronik adalah suatu proses dengan etiologi beragam, mengakibatkan penurunan fungsi ginjal yang progresif dan umumnya berakhir dengan gagal ginjal yang memerlukan terapi pengganti ginjal. Salah satu terapi pengganti ginjal yaitu hemodialisis. Subyek yang menjalani hemodialisis merupakan kelompok risiko tinggi untuk virus hepatitis B dan hepatitis C. Penelitian ini bertujuan untuk mengetahui skor APRI pada subyek PGK 5 HD dengan hepatitis B dan hepatitis C. Jenis penelitian ini ialah observasional dengan rancangan deskriptif retrospektif. Penelitian ini dilaksanakan mulai Oktober sampai Desember 2014 di Bagian rekam medik Ilmu Penyakit Dalam Unit Hemodialisis RSUP Prof Dr. R. D. Kandou Manado. Hasil penelitian memperlihatkan dari 64 subyek yang memenuhi kriteria inklusi terdapat 29 (45\%) subyek PGK 5 HD dengan hepatitis B dan 35 (55\%) subyek PGK 5 HD dengan hepatitis C. Pada subyek PGK stadium 5 HD dengan hepatitis B, terdapat 24 lakilaki (37,50\%) dan 5 perempuan (7,81\%). Pada subyek PGK 5 HD dengan hepatitis C, terdapat
\end{abstract}


15 laki-laki (23,43\%) dan 20 perempuan (31,25\%). Rentang umur pada subyek PGK 5 HD dengan hepatitis B 37-69 tahun sedangkan rentang umur pada subyek PGK 5 HD dengan hepatitis C 33-65 tahun. Nilai SGOT subyek PGK 5 HD dengan hepatitis B 14-58 U/L sedangkan subyek PGK 5 HD dengan hepatitis C 21-38 U/L. Jumlah trombosit pada subyek PGK 5 HD dengan hepatitis B $78.10^{3} / \mathrm{mm}^{3}-357.10^{3} / \mathrm{mm}^{3}$ sedangkan subyek PGK 5 HD dengan hepatitis C $54.10^{3} / \mathrm{mm}^{3}-417.10^{3} / \mathrm{mm}^{3}$. Berdasarkan nilai SGOT dan jumlah trombosit yang diperoleh maka hasil perhitungan skor APRI untuk subyek PGK 5 HD dengan hepatitis B 0,004-0,056 sedangkan pada subyek PGK 5 HD dengan hepatitis C 0,005-0,177. Skor APRI pada subyek PGK 5 HD dengan hepatitis B dan subyek PGK 5 HD dengan hepatitis C <0,5, yang menunjukkan tidak terdapat fibrosis pada hati atau terdapat fibrosis tanpa septa. Simpulan: Skor APRI tidak bermakna terhadap derajat fibrosis stadium awal baik pada hepatitis B ataupun heptitis C.

Kata kunci: PGK 5 HD, hepatitis B, hepatitis C, skor APRI

Penyakit Ginjal Kronik (PGK) adalah suatu proses dengan etiologi yang beragam, mengakibatkan penurunan fungsi ginjal yang progresif dan pada umumnya berakhir dengan gagal ginjal yang memerlukan Terapi Pengganti Ginjal (TPG). Modalitas TPG dapat dilakukan dengan: konservatif, dialisis (hemodialisis \& peritoneal dialisis) dan transplantasi ginjal.

The National Kidney Foundation Disease Outcomes Quality Initiative (NKFKDOQI) guidelines 2002 mendefinisikan PGK dengan kriteria: 1) Kerusakan ginjal selama $\geq 3$ bulan, meliputi kerusakan struktural atau abnormalitas fungsi ginjal dengan atau tanpa penurunan Laju Filtrasi Glomerulus (LFG) yang tampak dalam abnormalitas patologi atau marker kerusakan ginjal termasuk abnormalitas komposisi darah atau urin atau abnormalitas dalam hasil tes dan 2) $\mathrm{LFG}<60 \mathrm{~mL} / \mathrm{min} / 1,73 \mathrm{~m}^{2}$ selama $\geq 3$ bulan dengan atau tanpa kerusakan ginjal. ${ }^{2}$

Insidensi dan prevalensi end stage renal disease (ESRD) mengalami peningkatan menjadi dua kali lipat dalam sepuluh tahun terakhir dan diperkirakan akan terus mengalami peningkatan. Berdasarkan data yang dikumpulkan dari United State Renal Data Sistem (USRDS), pada tahun 1998 terdapat lebih dari 85.000 atau 308 per satu juta penduduk per tahun berisiko ESRD. Sebanyak 72\% melakukan terapi dialisis dan 28\% melakukan transplantasi ginjal pada lebih dari 320.000 atau 1.160 per satu juta populasi pada tanggal 31 Desember 1998. ${ }^{2}$ Di Indonesia jumlah pasien PGK meningkat pesat dengan angka kejadian gagal ginjal yang menjalani hemodialisis pada tahun 20022006 secara berturut-turut adalah 2077, 2039, 2594, 3556 dan 4334. ${ }^{3}$

PGK sering bersamaan dengan penyakit hati. Koeksistensi dari penyakit hati kronis pada pasien PGK yang menjalani hemodialisis merupakan penyebab penting morbiditas dan mortalitas. Pasien PGKberada dalam kelompok risiko tinggi terhadap paparan virus hepatitis karena berbagai alasan seperti gangguan humoral dan sistem imun seluler, transfusi darah, menggunakan mesin yang sama dan atau berbagi kamar yang sama dengan pasien yang terinfeksi, risiko penyebaran infeksi dari staf kesehatan pada saat periode dialisis. ${ }^{4}$ Hepatitis B dan hepatitis C kronik dapat menyebabkan fibrosis hati dan akhirnya menjadi sirosis, penyakit dekompensasi hati dan karsinoma hepatoselular. ${ }^{5}$

Aspartate aminotransferase to platelet ratio index (APRI) dapat digunakan untuk menilai derajat kerusakan hepar karena memiliki akurasi yang cukup tinggi dan sebagai prediktor non invasif. Metode penilaian berdasarkan uji noninvasif ini mempunyai sensitivitas dan spesifisitas tinggi terhadap perkembangan derajat fibrosis dan sirosis serta memberikan efekkomplikasi yang minimal bagi pasien. ${ }^{6}$ Penelitian ini dilakukan untuk mengetahui skor APRI pada subyek PGK 5 HD dengan hepatitis B dan hepatitis C. 


\section{METODE PENELITIAN}

Jenis penelitian ini observasional dengan rancangan deskriptif retrospektif. Penelitian ini dilakukan di Bagian Rekam Medik Ilmu Penyakit Dalam Unit Hemodialisis RSUP Prof Dr. R. D. Kandou Manado. Penelitian ini dilaksanakan selama bulan Oktober sampai Desember 2014. Populasi penelitian ialah semua pasien dengan diagnosis PGK 5 HD.

Kriteria inklusi penelitian ini ialah: laki-laki dan perempuan, usia 30-70 tahun, PGK 5 HD dengan hepatitis B, dan PGK 5 HD dengan hepatitis $C$ sedangkan kriteria eksklusi ialah pasien dengan data laboratorium yang tidak lengkap.

\section{HASIL PENELITIAN}

Pada penelitian ini didapatkan 64 subyek PGK 5 HD yang memenuhi kriteria inklusi (Tabel 1). Tabel 2 menunjukkan jenis kelamin laki-laki pada subyek PGK 5 HD dengan hepatitis B dengan jumlah 24 subyek (37,5\%) sedangkan pada subyek PGK 5 HD dengan hepatitis C dengan jumlah 15 subyek (23,43\%). Pada jenis kelamin perempuan subyek PGK 5 HD dengan hepatitis $\mathrm{B}$ dengan jumlah 5 syubyek (7,81\%) sedangkan subyek PGK 5 HD dengan hepatitis $C$ dengan jumlah 20 subyek (31,25\%).

Tabel 1. Karakteristik sampel penelitian berdasarkan umur, SGOT, trombosit dan skor APRI

\begin{tabular}{|c|c|c|c|c|c|c|}
\hline $\begin{array}{c}\text { Variabel } \\
\text { penelitian }\end{array}$ & (n) & & Min & Maks & Mean & $\begin{array}{l}\text { Standar } \\
\text { Deviasi }\end{array}$ \\
\hline \multirow{2}{*}{$\begin{array}{l}\text { Umur } \\
\text { (tahun) }\end{array}$} & PGK 5 HD dengan hep B & 29 & 37 & 69 & 51,97 & 8,699 \\
\hline & PGK 5 HD dengan hep C & 35 & 33 & 65 & 49,34 & 9,258 \\
\hline \multirow{2}{*}{$\begin{array}{l}\text { SGOT } \\
(\mathrm{U} / \mathrm{L})\end{array}$} & PGK 5 HD dengan hep B & 29 & 14 & 58 & 32,52 & 12,043 \\
\hline & PGK 5 HD dengan hep C & 35 & 21 & 138 & 43,57 & 22,813 \\
\hline \multirow{2}{*}{$\begin{array}{l}\text { Trombosit } \\
\left(/ \mathrm{mm}^{3}\right)\end{array}$} & PGK 5 HD dengan hep B & 29 & 78000 & 357000 & 182696,55 & 78655,753 \\
\hline & PGK 5 HD dengan hep C & 35 & 54000 & 417000 & 138428,57 & 62866,940 \\
\hline \multirow[t]{2}{*}{ Skor APRI } & PGK 5 HD dengan hep B & 29 & 0,004 & 0.056 & 0,02256 & 0,014187 \\
\hline & PGK 5 HD dengan hep C & 35 & 0,005 & 0,177 & 0,04170 & 0,038948 \\
\hline
\end{tabular}

Tabel 2. Karakteristik penelitian berdasarkan jenis kelamin.

\begin{tabular}{cccc}
\hline & \multicolumn{2}{c}{ Jenis Kelamin } & \multirow{2}{*}{ Total } \\
\cline { 2 - 3 } & Laki-laki & Perempuan & \\
\hline $\begin{array}{c}\text { PGK 5 HD dengan } \\
\text { hepatitis B }\end{array}$ & $24(37,5 \%)$ & $5(7,81 \%)$ & \\
\hline $\begin{array}{c}\text { PGK 5 HD dengan } \\
\text { hepatitis C }\end{array}$ & $15(23,43 \%)$ & $20(31,25 \%)$ & \\
\hline Total & $39(60,93 \%)$ & $25(39,06 \%)$ & $64(100 \%)$ \\
\hline
\end{tabular}

Tabel 3 menunjukkan bahwa pada subyek PGK 5 HD dengan hepatitis B yang memiliki skor APRI <0,5 yaitu sebanyak 29 subyek (100\%). 
Tabel 3. Skor APRI pada subyek PGK 5 HD dengan hepatitis $\mathrm{B}$

\begin{tabular}{cccc}
\hline Skor & \multicolumn{2}{c}{ Jenis Kelamin } & \multirow{2}{*}{ Total } \\
\cline { 2 - 3 } APRI & Laki-laki & Perempuan & \\
\hline \multirow{2}{*}{$<0,5$} & 24 & 5 & \\
& $(82,75 \%)$ & $(17,24 \%)$ & \\
\hline $0,5-1,5$ & 0 & 0 & \\
\hline$>1,5$ & 0 & 0 & \\
\hline \multirow{2}{*}{ Total } & 24 & $5(17,24 \%)$ & $\begin{array}{c}29 \\
(100 \%)\end{array}$ \\
\hline
\end{tabular}

Tabel 4 menunjukkan bahwa pada subyek PGK 5 HD dengan hepatitis $C$ yang memiliki skor APRI <0,5 yaitu sebanyak 35 subyek (100\%).

Tabel 4. Skor APRI pada subyek PGK 5 HD dengan hepatitis $\mathrm{C}$

\begin{tabular}{cccc}
\hline \multirow{2}{*}{$\begin{array}{c}\text { Skor } \\
\text { APRI }\end{array}$} & \multicolumn{2}{c}{ Jenis Kelamin } & \multirow{2}{*}{ Total } \\
\cline { 2 - 3 } & Laki-laki & Perempuan & \\
\hline$<0,5$ & $\begin{array}{c}15 \\
(42,85 \%)\end{array}$ & $\begin{array}{c}20 \\
(57,14 \%)\end{array}$ & \\
\hline $0,5-1,5$ & 0 & 0 & \\
\hline$>1,5$ & 0 & 0 & \\
\hline \multirow{2}{*}{ Total } & 15 & 20 & 35 \\
& $(42,85 \%)$ & $(57,14 \%)$ & $(100 \%)$ \\
\hline
\end{tabular}

\section{BAHASAN}

Pasien penyakit ginjal kronik dengan hepatitis B di Indonesia pada tahun 2012 ialah sebanyak 132 pasien dan hepatitis C sebanyak 144 pasien. ${ }^{7}$ Berdasarkan data tersebut jumlah pasien PGK dengan hepatitis $\mathrm{B}$ dan hepatitis $\mathrm{C}$ tergolong banyak.

Pada penelitian ini rentang umur subyek PGK 5 HD dengan hepatitis B adalah 37-69 tahun sedangkan rentang umur subyek PGK 5 HD dengan hepatitis C 33-65 tahun. Menurut The National Kidney Foundation Disease Outcomes Quality Initiative (NKF-KDOQI) guidelines, di antara populasi lansia terdapat lebih dari setengah subyek pada tahap CKD 3-5 $\left(\mathrm{LFG}<60 \mathrm{~mL} / \mathrm{min} / 1,73 \mathrm{~m}^{2}\right) .{ }^{8}$ Mcclellan dan Flanders ${ }^{9}$ membuktikan bahwa faktor risiko gagal ginjal salah satunya ialah umur yang lebih tua. Pada studi CREDIT yang dilakukan di Turkey rasio CKD berkisar
1,45-2,18 untuk setiap kenaikan 10 tahun pada usia subyek yang lebih tua dari 30 tahun. $^{10}$

Nilai SGOT pada penelitian ini terhadap subyek PGK 5 HD dengan hepatitis B ialah 14-58 U/L sedangkan subyek PGK 5 HD dengan hepatitis $C$ ialah 21-38 U/L. Penelitian ini serupa dengan penelitian Pondaag et al. ${ }^{11}$ yang menyatakan bahwa sedikit peningkatan kadar SGOT tidak selalu menunjukkan adanya penyakit hati, namun pemeriksaan laboratorium fungsi hati yang normal tidak selalu berarti bahwa hati tidak mengalami gangguan.

Jumlah trombosit pada subyek PGK 5 HD dengan hepatitis B $78.10^{3} / \mathrm{mm}^{3}-357$. $10^{3} / \mathrm{mm}^{3}$ sedangkan subyek PGK 5 HD dengan hepatitis C $54.10^{3} / \mathrm{mm}^{3}-417$. $10^{3} / \mathrm{mm}^{3}$. Sama halnya dengan penelitian yang dilakukan oleh Kaparang et al. ${ }^{12}$ pasien PGK yang menjalani hemodialisis pada umumnya mempunyai nilai trombosit normal.

Berdasarkan nilai SGOT dan jumlah trombosit yang diperoleh maka hasil perhitungan skor APRI untuk subyek PGK 5 HD dengan hepatitis B ialah 0,004-0,056 sedangkan pada subyek PGK 5 HD dengan hepatitis $C$ ialah 0,005-0,177.

Berdasarkan variabel penelitian menurut jenis kelamin bahwa pada PGK 5 HD dengan hepatitis B jumlah pasien lakilaki lebih banyak yaitu sejumlah 24 subyek (37,50\%) dari pasien perempuan dengan jumlah 5 subyek $(7,81 \%)$ sama dengan hasil penelitian yang dilakukan oleh Katayama et al. ${ }^{13}$

Pada variabel penelitian PGK 5 HD dengan hepatitis $\mathrm{C}$ jumlah pasien laki-laki yaitu 15 subyek (42,85\%) dan jumlah sampel perempuan lebih banyak dengan 20 subyek (57,14\%), sedangkan menurut Selm $^{14}$ penderita PGK 5 HD dengan hepatitis $\mathrm{C}$ jumlah pasien laki-laki lebih banyak yaitu 64\% dan perempuan 35\%.

Skor APRI pada subyek PGK 5 HD dengan hepatitis B dan subyek PGK 5 HD dengan hepatitis $\mathrm{C}$ dalam penelitian ini yaitu $<0,5$. Hal ini berarti tidak ada fibrosis pada hati atau terdapat fibrosis tanpa septa. 
Penelitian ini sesuai dengan penelitian yang dilakukan oleh Mata-Marin ${ }^{15}$ terhadap 80 pasien hepatitis $C$ kronis yang menyatakan bahwa APRI sebagai prediktor respon awal virus pada pasien hepatitis $C$ kronis tidak bermakna. Pada penelitian Elloumi pada tahun $2007^{16}$ terhadap 51 pasien hepatitis B kronis menyatakan bahwa APRI tidak bermakna dalam memprediksi kerusakan histopatologis pasien dengan penyakit hepatitis. Dengan demikian APRI tidak bermakna terhadap derajat fibrosis stadium awal baik pada hepatitis $\mathrm{B}$ ataupun hepatitis C.

\section{SIMPULAN}

1. Skor APRI pada PGK 5 HD dengan hepatitis B dan hepatitis C bernilai $<0,5$ yaitu non fibrosis hati.

2. Tidak bermaknanya skor APRI pada PGK 5 HD dengan hepatitis $B$ dan hepatitis C.

\section{SARAN}

Perlu dilakukan penelitian lebih lanjut untuk mengetahui skor APRI pada PGK 5 HD dengan hepatitis B dan hepatitis C.

\section{DAFTAR PUSTAKA}

1. Suwitra K. PGK. In: Sudoyo AW, Setiyohadi B, Alwi I, Simadibrata M, Setiati S, editors. Buku ajar ilmu penyakit dalam. Jakarta: EGC, 2009; p. 1035-40.

2. K/DOQI Clinical Practice Guidelines for Chronic Kidney Disease: Evaluation, Classification and Stratification. New York: National Kidney Foundation, 2002; p. 3-23.

3. Prodjosudjadi W, Suhardjono A. End stage renal disease in Indonesia: treatment development. Ethnicity \& Disease. 2009;19:33-6.

4. Sit D, Kadiroglu AK, Kayabasi H, Yilmas ME, Goral V. Seroprevalence of hepatitis $\mathrm{B}$ and $\mathrm{C}$ viruses in patients with chronic kidney disease in the predialisis stage at a University Hospital in Turkey. Intervirology. 2007;50:133-7.

5. Stibbe KJM, Verveer C, Francke J, HansenBE, Zondervan PE, Kuipers EJ, et al. Comparison of non-invasif assessment to diagnose liver fibrosis in chronic hepatitis B and C patients. Scandinavian Journal of Gastroenterology. 2011;46:962-72.

6. Soleh D, Arinton IG, Siswandari W. Hubungan APRI (Aspartat to platelet Ratio Index) terhadap derajat fibrosis pasien penyakit hati kronis. Mandala of Health. 2011;5:1-7.

7. Indonesian Renal Registry, 2012. $5^{\text {th }}$ Report of Indonesian Renal Registry. p. 17.

8. Iseki K. Factors influencing the development of end-stage renal disease. Clin Exp Nephrol. 2005;9:514.

9. Mcclellan, WM, Flanders WD. Risk Factor for progessive chronic kidney disease. J Ant Soc Nephrol. 2003;14:65-70.

10. Suleymanlar G, Utas C, Arinsoy $T$ et al. A population based survey of chronic renal disease In Turkey-the CREDIT study. Nephrol Dial Transplant. 2011;26:1862-71.

11. Pondaag F, Moeis E, Waleleng B. Gambaran enzim hati pada dewasa muda dengan obesitas sentral. eCl. 2014;2:1-4.

12. Kaparang J, Moeis ESY, Rotty L. Nilai trombosit pada pasien penyakit ginjal kronik, yang menjalani hemodialisis di Unit Hemodialisis Bagian/SMF Ilmu Penyakit Dalam FK Unsrat BLU RSUP Prof. Dr. R. D. Kandou Manado. 2013;1: 95-100.

13. Katayama K, Sato T, Do SH, Yamada H, Tabuchi A, Komiya Y, et al. Hepatitis B virus infection in hemodialysis patients in Japan: prevalence, incidence and occult hepatitis B virus infection. Hepatology Research. 2015;45:121119.

14. Selm SB. Prevalence of Hepatitis $C$ virus infection among hemodialysis patients in a single center in Yemen. Saudi J Dis Transplant. 2010;21(6):1165-8.

15. Mata-Marin JA, Fuentes-Allen JL, Gaytan-Martinez J, ManjarrezTelles B, Chaparro Sanches A, Arroyo-Anduiza C. APRI as a predictor of early viral respone in chronic hepatitis C patients. World J Gastroenterol. 2009;15:4923-27.

16. Hela E, Hefaiedh $R$, Khayatt $O$, Chedly 
Jarut, Moeis, Waleleng: Skor apri pada...

A, Zouari B, BelHadj N, Ghorbel

A. APRI score: Is it useful for Assessment of Fibrosis in Chronic
Hepatitis B? Arab Journal

Gastroenterology. 2007;8(4):136-7. 